Kong. Res. J. 4(2): 183-186, 2017

ISSN 2349-2694

Kongunadu Arts and Science College, Coimbatore.

\title{
ALLELOPATHIC INFLUENCE OF TRIANTHIMA PORTULACASTRUM L. ON GROWTH AND DEVELOPMENTAL RESPONSES OF SESAME (SESAMUM INDICUM L.)
}

\author{
Prabhakaran, J*. and D. Kavitha \\ Department of Botany, Annamalai University, Annamalai Nagar - 608 002, Tamil Nadu. \\ *E.mail: drprabha2006@gmail.com
}

\begin{abstract}
An experiment was conducted in order to determine the allelopathic effects of the aqueous extract of Trianthima portulacastrum L.on the seed germination, seedling growth and chlorophyll content ofsesame (Sesamum indicum L.). Greenhouse experiment was carried out as RCBD (Randomized complete block design) with four replications. Treatments included $0,1,2,3$ and $4 \%(\mathrm{~W} / \mathrm{W})$ residues of whole plant of T.portulacastrum with normal field soil. Results showed that the low concentrations of T.portulacastrum had no significant effect on the germination percentage, seedling length, dry weight, total chlorophyll contents at lower concentration(1\%) of weed residues. However, treatments with higher concentrations had negative effects on germination, growth and seedling dry weight of sesame.
\end{abstract}

Keywords: Allelopathy, Chlorophyll, Germination, Sesamum indicum, Trianthima portulacastrum.

\section{INTRODUCTION}

Allelopathy is a phenomenon of direct or indirect, beneficial or adverse effects of a plant on its own or another plant through the release of chemicals into the environment. It affects plant distribution, community formation, intercrop evolution and biodiversity conservation and is now arousing further international interest (Zhang et al., 2004). Allelopathy occurs in every ecosystem, from forests andgrasslands to deserts. Plants produce numerous chemical compounds during the period of growth. These compounds become free in terms of leaching gas from shoots, root discharges, or by decomposing of plants remaining at the environment (Roa, 2000). Chemicals extracted from plant roots or shoots (allelochemicals) have been shown to directly inhibit or stimulate germination, growth, and development of other plants (Putnam and Weston, 1986). The aim of this research was to evaluate the possible effects of the weed species, Trianthima portulacastrum $\mathrm{L}$. on the seed germination characteristics, seedling growth and chlorophyll content of sesame (Sesamum indicum L.). Sesame is a crop of greatantiquity which is widely grown in tropical and subtropical regions of Asia, Africa, South and North America and especially in Tamil Nadu of India for edible oil and for animal feed purposes.T. portulacastrum is an annual herb of flowering plant in the Aizoaceae known by the common names desert horse purslane, black pigweed, and giant pigweed. It is native to areas of several continents, including Africa and North and South America, and present as an introduced species in many other areas. It grows in a wide variety of habitat types and it can easily take hold in disturbed areas and cultivated land as a weed.

\section{MATERIALS AND METHODS}

This study was conducted to findout the allopathic influence of Trianthima portulacastrum L.on seed germination, initial growth properties and pigment changes of sesame (Sesamum indicum L.) cv TMV-1. T. portulacastrum (Fig.-1) were collected from crop fields located in Faculty of Agriculture, Annamalai University and the green house experiments were carried out at Botanical garden, Department of Botany, Annamalai University. The weeds were shade dried for12daysthenchopped to a fine pieces andwere mixed with soil at the proportion of $0 \%, 1 \%, 2 \%, 3 \%$ and $4 \%$ in $3 \mathrm{~kg}$ of garden soil. Earthen pots $(30 \times 15 \mathrm{~cm})$ werefilledwith different rate of weed residues and soil for the germination studies. The viable seeds of sesame were surface sterilized for two minutes in $0.2 \%$ mercuric chloride $\left(\mathrm{HgCl}_{2}\right)$, washed thoroughly in running tap water and sown @15 seeds/pot ${ }^{-1}$. Each pot was irrigated uniformly with normal tap water (pH-7.2) on alternate days up to the 15th day. Germination was recorded upto seventh day after seed sown (DAS). On the seventh and fifteenth day, growth characteristics such as seedling length, dry weight and total chlorophyll contents (Arnon, 1949) were recorded. The depth of significance between the treatments could be brought out clearly by multiple range testing programme.

\section{RESULTS AND DISCUSSION}

The green house studies showed that the weed residues of $T$. portulacastrum significantly 
reduced germination of sesameover the control and the magnitude of reduction differed depending upon the concentration of the weed residues employed (Fig. 2-5). The 1\% residues slightly inhibited germination while the residues of higher concentrations the seeds were drastically reduced their germination potential. Seed germination is considered to be the most critical stage especially under stress conditions. During germination, biochemical changes take place, which provides the basic framework for subsequent growth and development. The initial metabolic changes that occur immediately after the imbibitions of water are the increase in the hydrolytic enzymes, such as alpha-amylase and protease. Alphaamylase is an important starch degrading enzyme in the endosperm. The reaction products provide substrate and an energy source for the embryo during germination. The inhibition of seed germination is also due to disturbance in the activities of peroxides, alpha-amylase, and acid phosphates. Inhibition of seed germination of crop plants is also due to disturbance in the activities of peroxidase, alphaamylase and acid phosphates (Alam and Islam, 2002) The results of present study revealed the marked allelopathic potential of $T$. portulacastrum on sesame. These results are in accordance with the findings of Meihua et al. (2006) who reported inhibitory effects of water extracts of Lactariushatsudake on seedling growth of rape (Brassica campestris) and radish (Raphanus sativus).

\section{Fig.1. Trianthima portulacastrum}

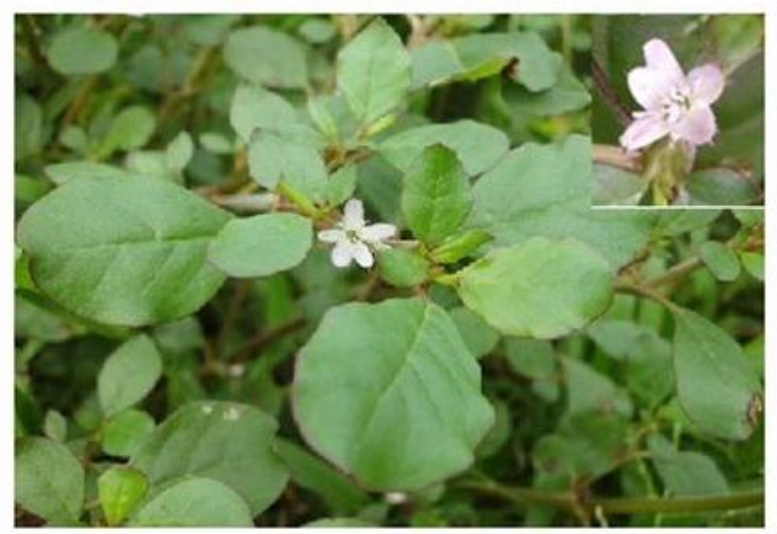

The weed T. portulacastrum contains watersoluble bases and potassium salts , punarnavine and a new alkaloid , trianthemine and ecdysterone are present in the aerial parts. They also contain oxalic acid. 5,2-dihydroxy-7-methoxy-6,8-dimethylflavone and 5,7- dihydroxy -6,8- dimethyl- chromone (leptorumol). Roots contain saponin glycoside (Ghani, 2003). Sherif and Gharieb (2011) reported the presence of P-Hydroxybenzoic acid, Caffeic acid, Vanillicacid,ferrulic acid, o-coumaric acid, Pyrogallic acid, Protocatechuic acid and trans-Cinnamicacidin the leaves andstem of $T$. portulacastrum. These allelochemicals play an important role in allelopathic interactions, and their biological activities on growth of some crop plants and weeds were studied using different bioassay tests (Chung et al., 2002).

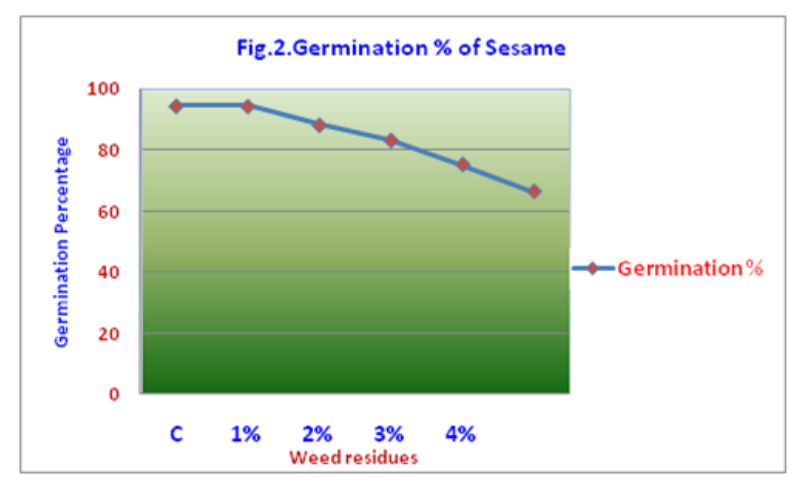

Fig.3. Seedling length ( $\mathrm{cm} /$ plant) of sesame
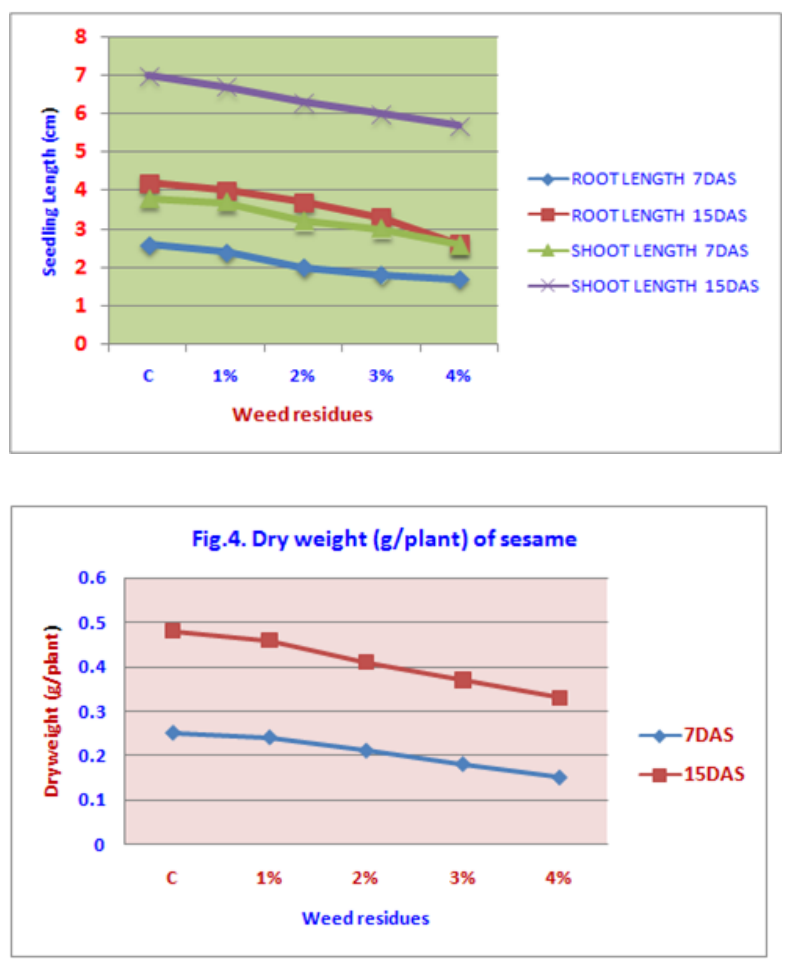

Fig.5. Total Chlorophyll contents (mg/g fr.wt.) of sesame

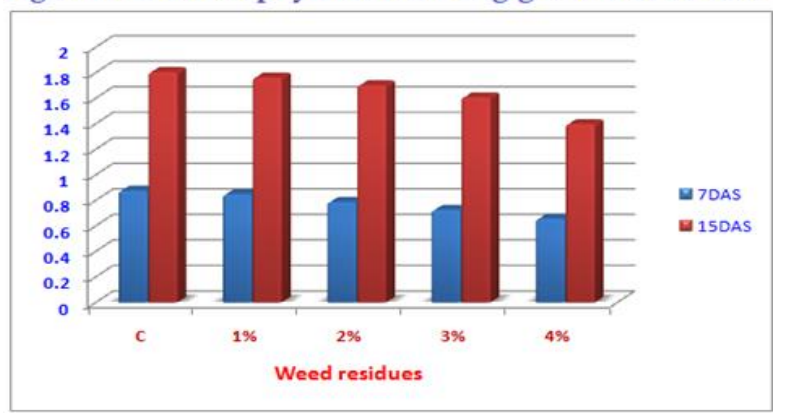


It seemsthat these compounds together with someother unknown compounds in $T$. portulacastrum are responsible for its allelopathic behaviors. Residues of T.portulacastrum significantly decreased and delayed the seed germination of target plants withincreasing residual concentration, that is, from control $(0 \%)$ to $4 \%$, the degree of inhibition increased. The allelopathic effects of Scariola orientalis and Agropyron elongatum were studied on Onobrychis viciaefolia germination propertiesby Rezaei and Khajeddin (2008). They found that theextracts of the two allelopathic species significantly decreased the seed germination, germination rate, andgermination speed of 0 . viciaefolia. Allelopathic extract could be confounded with osmoticeffects on rate of inhibition, delayed initiation of germination,and especially cell elongation (Black, 1989); the mainfactor that affects root growth before and after the tippenetrates the seed coat (Bewley and Black, 1978). Bhawmik and Doll (1982) stated that allelopathy influencedseed germination and seedling development bypreventing cell division and inhibiting cell elongation.Avers and Goodwin (1956) reported that phenolic compounds,as main parts of allelochemicals, prevented rootcell division. From studies using aqueous alfalfa leafextract by Chon et al. (2004), they concluded that delayedseed germination and, especially, reduced root elongationwere due mainly to toxic factors of the leaf extract

The results of seedling lengthand dry weight are presented in tables-1\& 2 . Aqueous extract of T. portulacastrum decreased the root length, shoot length and fresh weight of sesame in both the sampling days. The adverse effect gradually increased which resulted in the growth and biomass decreased in the sesame seedlings. The probable reason could be the inhibitory effect of allelochemicals in uptake of water by seedlings and reduction in other physiological processes of the crop. The reduction in dry weight per seedling was due to reduction in root length and root thickness.Water soluble inhibitors could be the reason of reducing the root and shoot length of rice significantly (Kil and Yun, 1992). Cell division might have been affected which reduced the root and shoot lengths of rice seedlings as allelopathic compounds are known to inhibit functioning of gibberellin and indole acetic acid (Tomaszewski and Thimann 1966).Several studies have noticed that many secondary metabolites are released into the environment, either as exudation from living plant tissues or by decomposition of plant material under certain conditions (Einhelling, 1995). These chemicals like phenolics, terpenoids and alkaloids and their derivatives are potential inhibitors of germination, seedling growth, fresh weights and dry weights (Herro and Callaway, (2003); Siddiqui and Zaman, (2004); Siddiqui and Zaman (2005).

The photosynthetic pigmentstotal chlorophyll contents were gradually decreased with increasing the quantity of T. portulacastrum residues (Fig. 2).The decrease in chlorophyll synthesis is a common response of plants toallelochemicals, and this might be a subsequent response of plant to these chemicals beside cellular damage. Allelochemicals adversely affect chlorophyll biosynthesis and accumulation by interfering in chlorophyll biosynthesis and/or destruction. The upcoming negative effects of these processes would be retarding of photosynthesis and poor plant growth (Tanveer et al., 2008).

\section{CONCLUSION}

The present findings revealed that residues of T. Portulacastrum at various quantity levels inhibited the germination, growth and reduced dry weights of sesame seedlings. The germination and growth suppression of sesame seedlings indicate that the allelochemicals released into soil after decomposition residues of $T$. portulacastrum. Further, the detailed studies are required to explain the possible physiological mechanism related to allelopathic effects on soil health and other plants.

\section{REFERENCES}

Alam, S.M. and E.U. Islam, (2002). Effect of aqueous extract of Leaf, stem and root of nettle leaf goosefoot and $\mathrm{NaCl}$ on germination and seedling growth of rice. Pak. J. Sci. Tech 1(2): 47-52.

Avers, C.J. and R.H. Goodwin, (1956). Studies on roots IV. Effects of coumarin and scopoletin on the standard root growth pattern of Phleum pratens. Am. J Bot 43(8): 612-620.

Bewley, J.D. and M. Black, (1978). Physiology and Biochemistry of Seeds in Relation to ermination. New York: Springer-Verlag, 1: 128130.

Bhawmik, P.C. and J.D. Doll, (1982). Corn and soybean response to allelopathic effects of weed and crop residues. Agron J 74: 601-606.

Black, M. (1989). Seed research-past, present and future. In: Taylorson, R.B, (eds.), Recent advances in the Development and Germination of Seeds. New York: Plenum, pp. 1-6.

Chon, S.U., C.J. Nelson and J.H. Coutts, (2004). Osmotic and autotoxic effects of leaf extracts on 
germination and seedling growth of alfalfa. Agron J 96: 1673-1679.

Chung, I.M., KH. Kim, J.K. Ahn, S.C. Chun, C.S. Kim, J.T. Kim and S.H. Kim, (2002). Screening of allelochemicals on barnyardgrass (Echinochloa crus-galli) and identification of potentially allelopathic compounds from rice (Oryza sativa) variety hull extracts. Crop Prot 21: 913-920.

Einhelling, F.A. (1995). Mechanism of action of allelochemicals in allelopathy.In Allelopathy: organisms, processes, and applications. K. Inderjit, M.M. Dakshini and F.A. Einhellig (eds.). American Chem Soc 96-116.

Ghani, A. (2003). Medicinal Plants of Bangladeshchemical constituents and uses, $2^{\text {nd }}$ ed, The Asiatic Society of Bangladesh, Dhaka, Bangladesh, pp. 362-363, 502-505

Herro, J.L. and R.M. Callaway, (2003). Allelopathy and exotic plant invasion. Plant and Soil 256: 29-39.

Khuram, M., N. Muhammad, A. Tanveer and Z. Zahir Ahmad, (2011). Allelopathic Effect of Aqueous Extracts of Weeds on the Germination and Seedling Growth of Rice (Oryza sativa L.). Pak. J. Life Soc. Sci 9(1): 7-12

Kil, B.S. and K.W. Yun, (1992). Allelopathic effects of water extracts of Artemesia princeps var. Orientalis on selected plant species. J. Chemical Ecology 18: 1933-1940.

Meihua, M., O. Xiao, Y. Zhang and C. Nie, (2006). Allelopathy of aqueous leachates of Lactariushatsudake on several crops and barnyard grass (Echinochloa crussgalli L.). Proceedings, $4^{\text {th }}$ World Congress on Allelopathy, 2006, August, Wagga, Australia.
Putnam, A.R. and L.A. Weston (1986). Adverse impacts of allelopathy in agricultural system. In: Putnam, A.R. Tang, S.C. (eds.), The Science of Allelopathy. New York: John Wiley and Sons, Inc, pp. 235-239.

Sherif, A. and H.R. Gharieb, (2011). Allelochemical effect of Trianthema portulacastrum L. on Amaranthus viridis L. supports the ecological importance of allelopathy. African J. Agri. Res 6(32): 6690-6697.

Siddiqui, Z.S. and A.U. Zaman, (2004). Effects of systemic fungicide (benlate) on germination, seedling growth, biomass and phenolic contents of two different varieties of Zea mays. Pak. J. Bot 36: 577-582.

Siddiqui, Z.S. and A.U. Zaman, (2005). Effects of capsicum leachates on germination, seedling growth and chlorophyll accumulation in Vigna radiata L. Wilczek. seedlings. Pak. J. Bot 37(4): 941- 947.

Tanveer, A., M. Tahir, M.A. Nadeem, M. Younis, A. Aziz and M. Yaseen, (2008). Allelopathic effects of Xanthium strumarium L. on seed germination and seedling growth of crops. Allelopath. J 21(2): 317-328.

Tomaszewski, M. and K.V. Thimann, (1966). Interactions of phenolic acids, metallic ions and chelating agents on auxin induced growth. Plant Physiology 41: 1443-1454.

Zhang, Kai Mei, Shi Lei and Li Zhen Yu, 2004.Fern allelopathy and its impact on biodiversity. Biodiversity Science 12: 466-471. 